\title{
Gel Electrolytes of Covalent Network Polybenzimidazole and Phosphoric Acid by Direct Casting
}

Kirkebæk, Andreas; Aili, David; Henkensmeier, Dirk; Jensen, Jens Oluf; Li, Qingfeng

Published in:

Macromolecular Materials and Engineering

Link to article, DOI:

10.1002/mame.201700347

Publication date:

2017

Document Version

Peer reviewed version

Link back to DTU Orbit

Citation (APA):

Kirkebæk, A., Aili, D., Henkensmeier, D., Jensen, J. O., \& Li, Q. (2017). Gel Electrolytes of Covalent Network Polybenzimidazole and Phosphoric Acid by Direct Casting. Macromolecular Materials and Engineering, 302(12), [1700347]. https://doi.org/10.1002/mame.201700347

\section{General rights}

Copyright and moral rights for the publications made accessible in the public portal are retained by the authors and/or other copyright owners and it is a condition of accessing publications that users recognise and abide by the legal requirements associated with these rights.

- Users may download and print one copy of any publication from the public portal for the purpose of private study or research.

- You may not further distribute the material or use it for any profit-making activity or commercial gain

- You may freely distribute the URL identifying the publication in the public portal 


\title{
Communication
}

\section{Gel electrolytes of covalent network polybenzimidazole and phosphoric acid by direct casting ${ }^{\mathrm{a}}$}

Andreas Kirkebæk, David Aili,* Dirk Henkensmeier, Jens Oluf Jensen and Qingfeng Li

\author{
A. Kirkebæk, Dr. D Aili, Prof. J. O. Jensen, Prof. Q. Li \\ Department of Energy Conversion and Storage, Technical University of Denmark, Kemitorvet 207, \\ DK-2800 Kgs. Lyngby, Denmark \\ E-mail: larda@dtu.dk
}

Dr. D. Henkensmeier

Fuel Cell Research Center, Korea Institute of Science and Technology (KIST), 39-1, Hwarangno 14gil5, Seongbukgu, 02792 Seoul, Republic of Korea

ET-GT, University of Science and Technology, Seoul 02792, Republic of Korea

Green School, Korea University, Anam-ro 145, Seongbukgu, Seoul 02841, Republic of Korea

* Corresponding author

Polybenzimidazole membranes imbibed with phosphoric acid can support high proton conductivity at $120-200{ }^{\circ} \mathrm{C}$, and have therefore emerged as the state-of-the-art electrolytes for fuel cells operating in this temperature range. This work presents a novel and operationally simple methodology for preparing mechanically robust covalent network polybenzimidazole membranes containing up to 95 wt $\%$ phosphoric acid. Diamino-terminal pre-polymers of different chain lengths were first prepared, followed by addition of a trifunctional carboxylic acid. The crude solutions were cast and subsequently heat treated at up to $230{ }^{\circ} \mathrm{C}$, yielding free-standing membranes of networked polybenzimidazole with high proton conductivity at up to $180{ }^{\circ} \mathrm{C}$ and encouraging fuel cell performance.

\footnotetext{
a Supporting Information is available online from the Wiley Online Library or from the author.
} 


\section{Introduction}

Binary systems of phosphoric acid immobilized in polymer matrices can support high proton conductivity at low water activities up to $200{ }^{\circ} \mathrm{C}$, and are thus widely employed as high temperature polymer electrolyte membranes. ${ }^{[1]}$ The concept was first proposed by Wainright et al., ${ }^{[2]}$ who replaced water with phosphoric acid as the proton solvent in perfluorosulfonic acid membranes. However, due to severe complications with concentration polarization the practical value as fuel cell electrolyte was limited. ${ }^{[3]}$ Immobilizing phosphoric acid in poly[2,2-( $m$-phenylene $)-5,5^{\prime}$-bibenzimidazole $](m$-PBI, see structure in Scheme 1) was a considerably more successful approach and its discovery resulted in a major breakthrough in the field. ${ }^{[4]}$

A large number of polybenzimidazole structure derivatives, ${ }^{[5]}$ polyimides ${ }^{[6]}$ and aromatic polysulfones bearing pyridine units in the main chain ${ }^{[7]}$ or as tethered side-groups ${ }^{[8]}$ have been developed as base materials for this purpose throughout the years. The chemistry of such semi-solid polymer electrolytes is highly complex as they are in addition to the base polymer composed of water as well as various phosphoric oxo-acid species. ${ }^{[9]}$ Although the physicochemical properties depend on the preparation method, ${ }^{[10]}$ a general understanding is that the proton conductivity at a certain temperature and water activity increases with increasing acid content. For example, for $m$-PBI with an acid content of 4-10 $\mathrm{H}_{3} \mathrm{PO}_{4}$ per polymer repeat unit it typically reaches $0.04-0.08 \mathrm{~S} \mathrm{~cm}^{-1}$ at $180{ }^{\circ} \mathrm{C} \cdot{ }^{[11]}$ Under similar conditions the conductivity of alternative polybenzimidazole structures prepared according to the sol-gel method with $>20 \mathrm{H}_{3} \mathrm{PO}_{4}$ per polymer repeat can reach as high as 0.2 $\mathrm{S} \mathrm{cm}^{-1} \cdot{ }^{[12]}$

The phosphoric acid within the structure indeed supports remarkably high proton conductivity, but it also exerts a strong plasticizing effect. As a result, the tensile strength ${ }^{[13]}$ as well as the creep resistance ${ }^{[14]}$ decreases and improving the mechanical robustness at high acid loadings has therefore been a key strategy in the development process. Here, increasing the linear molecular 
weight of the polymer, ${ }^{[15]}$ reinforcement with porous polytetrafluoroethylene ${ }^{[16]}$ or nanoparticles, ${ }^{[17]}$ and various crosslinking methods involving thermal treatment, ${ }^{[18]}$ Friedel-Crafts chemistry, ${ }^{[19]} \mathrm{N}$ functionalization, ${ }^{[20]}$ phosphoric acid ester bridging ${ }^{[21]}$ or electron beam irradiation ${ }^{[22]}$ have proven successful. Addition of trifunctional carboxylic acid monomers to $N$-terminal pre-polymers represent an interesting approach in connection to covalent crosslinking, but the obtained materials present severe processing difficulties due to the formation of an insoluble covalent network polymer. ${ }^{[23]}$

In this work, the sol-gel processing methodology ${ }^{[12,24]}$ was combined with the covalent network chemistry as described by Xu et al. ${ }^{[23 a, 23 b]}$ This was achieved by synthesizing $m$-PBI prepolymers of different chain lengths and with diamino-functional terminal groups, followed by addition of a trifunctional carboxylic acid before tape-casting on a glass substrate. A subsequent heat treatment produced gel membranes with high phosphoric acid content, showing increased tensile strength and conductivity well above $100 \mathrm{mS} \mathrm{cm}^{-1}$ at $120-180{ }^{\circ} \mathrm{C}$.

\section{Experimental Section}

\subsection{Materials}

3,3'-diaminobenzidine (DAB, $\geq 98 \%$ ) was acquired from Glentham Life Sciences, stored at $-18^{\circ} \mathrm{C}$ and dried at $110{ }^{\circ} \mathrm{C}$ under vacuum overnight prior to use. Isophtalic acid (IPA, 99\%, dried under vacuum at $110{ }^{\circ} \mathrm{C}$ ), benzene-1,3,5-tricarboxylic acid (BTA, 95\%, Sigma-Aldrich), orthophosphoric acid (PA, 85\% $\mathrm{H}_{3} \mathrm{PO}_{4}$ ), polyphosphoric acid (PPA, 115\% PA, reagent grade), $\mathrm{LiCl}$ (technical grade), potassium hydrogen phthalate (PHP), sodium hydroxide $(\mathrm{NaOH}), N, N$-dimethylacetamide (DMAc), dimethylsulfoxide (DMSO) were supplied by Sigma-Aldrich and used as received unless otherwise stated.

\subsection{Polymerization and film formation}


The pre-polymers were obtained by mixing DAB and IPA in PPA in a reaction vessel equipped with an overhead mechanical stirrer, argon in- and outlet and thermometer. The stoichiometry was controlled to give diamino-terminal pre-polymers with theoretical degrees of polymerization of 25 , 50 and 75 (hereafter referred to as DP25, DP50 and DP75, respectively), see Table S1 for details. As a general procedure, the mixture was heated to $150{ }^{\circ} \mathrm{C}$ under a flow of argon and stirred for $20 \mathrm{~h}$ to form a homogeneous solution. The temperature was thereafter increased to $220{ }^{\circ} \mathrm{C}$ and the homogeneous solution was stirred for additionally $4 \mathrm{~h}$ and thereafter cooled to $120^{\circ} \mathrm{C}$. A sample was collected, acid-neutralized and used for further analysis. BTA was added to the remaining solution, which was stirred at $120{ }^{\circ} \mathrm{C}$ for 30 minutes before the crude solution was cast to a thickness of 300 $\mu \mathrm{m}$ on a glass substrate using a doctorblade. The produced film was then heat-treated at $150{ }^{\circ} \mathrm{C}$ for $12 \mathrm{~h}$ and at $230{ }^{\circ} \mathrm{C}$ for $4 \mathrm{~h}$. Heat-treatment was performed in air using a heating rate of $60{ }^{\circ} \mathrm{C} \mathrm{h}^{-1}$. To slowly hydrolyze the PPA to PA, the films were placed in a closed container over an aqueous solution of $\mathrm{LiCl}(1 \mathrm{wt} \%)$ for at least $72 \mathrm{~h}$ to adjust the nominal relative humidity to around $88 \%$. The obtained membranes were subsequently equilibrated at room temperature in $85 \mathrm{wt} \% \mathrm{H}_{3} \mathrm{PO}_{4}$ and stored in the acid until use.

\subsection{Characterization}

The gel content of the membranes was determined on the dry membrane basis (after extensive washing in water and dilute aqueous sodium hydroxide (hereafter referred to as de-doping) by treating the samples in DMAc at $120{ }^{\circ} \mathrm{C}$ for $24 \mathrm{~h}$. The PA content was determined by extracting $4 \times 1 \mathrm{~cm}^{2}$ samples in $400 \mathrm{~mL}$ water for $24 \mathrm{~h}$, which was titrated with a standardized aqueous $\mathrm{NaOH}$ solution using an 808 Titrando from Metrohm. The PA content was calculated based on the second equivalence point. For comparison, the PA content was also determined gravimetrically based on the weight before and after de-doping. The viscosity was determined at $30{ }^{\circ} \mathrm{C}$ in DMSO or $96 \% \mathrm{H}_{2} \mathrm{SO}_{4}$ 
at a sample concentration of about $0.5 \mathrm{~g} \mathrm{dL}^{-1}$ using an Ubbelohde viscometer. The Fourier transform infrared spectra were recorded on a Perkin Elmer Spectrum Two in attenuated total reflectance (ATR) mode. The ${ }^{1} \mathrm{H}$ nuclear magnetic resonance $\left({ }^{1} \mathrm{H} \mathrm{NMR}\right)$ spectra were recorded on a Bruker Ascend operating at $400 \mathrm{MHz}$, using deuterated dimethylsulfoxide (DMSO- $d_{6}$ ) as solvent and using the solvent residual signal at $2.50 \mathrm{ppm}$ as internal reference. Thermogravimetric data were acquired under air at a linear heating rate of $5^{\circ} \mathrm{C} \mathrm{min}^{-1}$, using a Netsch STA 409 PC. X-ray diffraction (XRD) was carried out using a Rigaku MiniFlex 600 equipped with a $\mathrm{Cu} \mathrm{K} \alpha$ X-ray source $(\lambda=1.5418 \AA)$ in the range of $5-90^{\circ} 2 \theta$ at a scan rate of $2^{\circ} 2 \theta \mathrm{min}^{-1}$ and a step size of $0.02^{\circ} 2 \theta$. Tensile testing was performed using a modified universal materials testing machine (Testometric Micro 350) at a crosshead speed of $10.00 \mathrm{~mm} \mathrm{~min}^{-1}$. Dog-bone shaped specimens (2.0 mm wide and $28 \mathrm{~mm}$ long) were prepared by die-cutting and dried in vacuum at $60{ }^{\circ} \mathrm{C}$ for at least 12 hours. The in-plane conductivity was determined at $120-180{ }^{\circ} \mathrm{C}$ under ambient air using a four-probe in-plane conductivity cell. A symmetric square wave current $(2-5 \mathrm{kHz})$ was applied via platinum foils and the voltage drop across $1 \mathrm{~cm}$ was measured using an Yokogawa DL1100 oscilloscope.

Fuel cell membrane-electrode assemblies were prepared by sandwiching the DP50 membrane between two pieces of HT140E-W gas-diffusion electrodes with a Pt loading of $0.5 \mathrm{mg} \mathrm{cm}{ }^{-2}$ acquired from E-Tek (active area $1 \mathrm{~cm}^{2}$ ). The cells were operated by passing air at a rate of $150 \mathrm{~mL} \mathrm{~min} \mathrm{~m}^{-1}$ over the cathode and dry hydrogen at a rate of $50 \mathrm{~mL} \mathrm{~min}^{-1}$ over the anode at ambient pressure. Constant current operation was performed at $200 \mathrm{~mA} \mathrm{~cm}^{-2}$.

\section{Results and Discussion}

By controlling the relative DAB:IPA molar ratio during the pre-polycondensation at 1.040-1.013, linear diamino-terminal pre-polymers were obtained with targeted degrees of polymerization of 25 , 
50 and 75. The identity of the linear pre-polymers was confirmed by ${ }^{1} \mathrm{H}$ NMR and FT-IR, showing the main spectral features of $m$-PBI as assigned and discussed in more detail elsewhere. ${ }^{[25]}$

The ${ }^{1} \mathrm{H}$ NMR of the DP25 pre-polymer is shown in Figure 1a, showing several peaks in the region 6.5-7.0 ppm. This is a characteristic region for aromatic protons of the amino-terminal groups (compare with the spectrum of the DAB monomer), and supports that the pre-polymers contain active terminal groups for further network formation. Furthermore, as shown in Figure 1b the FT-IR of the DP25 pre-polymer showed a strong broad absorption peak around $3000 \mathrm{~cm}^{-1}$, which is characteristic for hydrogen-bonded N-H groups. ${ }^{[2]}$ As shown in Figure 1c, the thermo-oxidative stability increased with increasing chain length of the linear pre-polymer, showing onset temperatures of major decomposition of 500, 513 and $570{ }^{\circ} \mathrm{C}$ for DP25, DP50 and DP75, respectively.

The inherent viscosity of the de-doped polymer sampled from the crude solution after the prepolymerization increased with increasing theoretical degree of polymerization, as shown in Figure 1d. For example, the inherent viscosity of DP25 as measured in $\mathrm{H}_{2} \mathrm{SO}_{4}$ was $0.51-0.81 \mathrm{dL} \mathrm{g} \mathrm{g}^{-1}$, corresponding to about $28000 \mathrm{~g} \mathrm{~mol}^{-1} \cdot{ }^{[27]}$ For the DP50 and DP75 samples, the inherent viscosity was as high as 1.11-1.55 and 1.92-3.10 $\mathrm{dL} \mathrm{g}^{-1}$, respectively. Significant batch-to-batch deviations were observed as a result of small variation in the reaction conditions. ${ }^{[28]}$ The inherent viscosity of the linear $m$-PBI pre-polymers was considerably higher than what is normally observed for $m$-PBI in sulfuric acid, ${ }^{[15 b]}$ likely due to altered chain conformation in solution due to the charged terminal diamino groups.

The process for obtaining the free-standing membranes based on a $m$-PBI network structure is illustrated in Scheme 1. The degree of polymerization of the linear pre-polymers determined the spacing between three-way connections in the network structure of the polymer.

As shown in the inset in Scheme 1, the cast crude solution appeared as a transparent yellow film. The film contracted during the heat treatment resulting in decreased surface area and increased 
thickness. However, dark brown free-standing films were obtained after hydrolysis of the PPA in air at room temperature and $88 \%$ relative humidity for $72 \mathrm{~h}$. The gel content of the polymer fraction of the de-doped membranes, i.e. the fraction of the polymer that is insoluble in DMAc, was 84, 75 and 72 wt\% for DP25, DP50, and DP75, respectively (see Figure S1). This qualitative measure can be taken as an indicator of the degree of crosslinking, ${ }^{[18,20 \mathrm{a}]}$ and the high gel contents of the membranes in the present work clearly support the polymer network formation.

To prevent further leaching of PA, the membranes were equilibrated and stored in $85 \%$ PA. The phosphoric acid contents are summarized in Table 1, and ranged of about 91-95 wt $\%$. This corresponds to $39-55 \mathrm{H}_{3} \mathrm{PO}_{4}$ per polymer repeat unit assuming $308 \mathrm{~g} \mathrm{~mol}^{-1}$ as the repeat unit molar mass, similar to that obtained for direct cast membranes based on linear polybenzimidazole chemistries. $^{[12,14]}$

As shown in Figure 2a, the XRD of the membrane after the heat treatment step showed a broad peak centered around $2 \theta 25^{\circ}$ for DP50 and DP75, as commonly observed for phosphoric acid doped $m$-PBI membranes and indicating an amorphous structure with some degree of order on the sub-nanometer scale after heat treatment. ${ }^{[10,18]}$ The amorphous halo of the DP25 membrane was centered at $2 \theta 18^{\circ}$, likely due to the relatively short linear polymer segments. After equilibration in phosphoric acid, the membranes remained fully amorphous.

Due to the high acid-contents, the network membranes showed significantly lower tensile strength and elastic modulus as compared with the reference membrane prepared by casting from DMAc (Figure 2b). The tensile strength at break (around $1 \mathrm{MPa}$ ) was, however, similar to that of membranes based on linear $m$-PBI with lower acid contents as reported in the literature. ${ }^{[10]}$ The elastic modulus of the DP25 membrane with an acid content corresponding to $49-55 \mathrm{H}_{3} \mathrm{PO}_{4}$ per polymer repeat unit was about 6.6 $\mathrm{MPa}$, which can be compared with 1.9 for a membrane based on linear $p$ PBI with an acid content of $28 \mathrm{H}_{3} \mathrm{PO}_{4}$ per polymer repeat unit. ${ }^{[29]}$ The relatively high elastic modulus 
of the DP25 membrane, as commonly observed for covalently crosslinked $m$-PBI, ${ }^{[20 b]}$ further supports the polymer network formation. Despite slightly lower acid contents, the elastic modulus decreased with increasing chain length of the pre-polymers, as summarized in Table 1. At the same time, the elongation at break increased due the increasing spacing between the three-way connections in polymer network structure.

As shown in Figure $3 \mathrm{a}$, the proton conductivity at $120{ }^{\circ} \mathrm{C}$ was initially very high and reached around $0.3 \mathrm{~S} \mathrm{~cm}^{-1}$, i.e. close to that of pure orthophosphoric acid ${ }^{[30]}$ and in good agreement with the data reported for direct cast membranes based on linear polybenzimidazole with similar acid contents. ${ }^{[12,21]}$ However, due to loss of water during the initial hours ${ }^{[28]}$ the conductivity dropped significantly and stabilized at around $0.1 \mathrm{~S} \mathrm{~cm}^{-1}$, which is still higher than that of the membrane cast from DMAc with an acid content of about $10 \mathrm{H}_{3} \mathrm{PO}_{4}$ per polymer repeat unit. The conductivity slightly increased by further heating to $160{ }^{\circ} \mathrm{C}$, and thereafter declined slightly at $180{ }^{\circ} \mathrm{C}$ due to phosphoric acid condensation. ${ }^{[18,31]}$ A deeper quantitative discussion about the sample-to-sample conductivity variations for the prepared membranes is likely not feasible at this stage, due to e.g. uncertainties in compositional and dimensional changes of the membranes under the experimental conditions.

Fuel cell polarization curves of a MEA based on the DP50 membrane are shown in Figure 3b, together with polarization curves of reference cells based on post-doped $m$-PBI cast from DMAc. The cells were operated at high over-stoichiometry of both hydrogen and air (>30), as an initial assessment of the new electrolyte. The higher activation loss as observed in the low current density range of the DP50 cell is likely due to partial phosphoric acid flooding of the catalyst layers. ${ }^{[32]}$ It should also be remarked that the catalyst loading of the electrodes was 3 times lower than that of the reference cell, which has a large impact on the activation overpotential. In the higher current density range, the electrode flooding is evidenced by mass transport limitations, particularly at 120 and $150{ }^{\circ} \mathrm{C}$. 
Furthermore, the DP50 membrane was considerably thicker than the linear reference membrane. In order to compensate for the thickness differences, the in-situ conductivities were calculated based on an estimation of the ohmic resistance by a linear fit to the polarization data in the current density range $350-1170 \mathrm{~mA} \mathrm{~cm}^{-2}$. For the DP50 membrane, the in-situ conductivity reached $106 \mathrm{mS} \mathrm{cm}^{-1}$ and was in good agreement with the data in Figure 3a. Even though the area specific resistance of the cell based on the linear reference membrane was comparable to that of the DP50, the corresponding insitu conductivity was considerably lower $\left(21 \mathrm{mS} \mathrm{cm}^{-1}\right)$.

As stated above, the high phosphoric acid loadings present major challenges with respect to performance optimization. The phosphoric acid tend to redistribute during cell operation, ${ }^{[33]}$ and further optimization of the electrodes and of the membrane-electrode interfaces is thus needed to maintain the phosphoric acid within the novel networked membranes and ultimately improve their cell performance. Acid leaching and redistribution represent predominating fuel cell degradation mechanisms, ${ }^{[34]}$ and mechanically robust membranes with exceptionally high acid inventory could therefore become an important part of the overall degradation mitigation strategy. As shown in the inset in Figure 3b, the preliminary short-term stability tests indicate stable performance during a few days of operation.

\section{Conclusions}

Addition of a trifunctional carboxylic acid to the crude phosphoric acid solution of diamino-terminal polybenzimidazole pre-polymers produced networked polybenzimidazole membranes after casting and heat treatment. The method produced mechanically robust membranes with phosphoric acid contents as high as 90-95 wt\%, supporting proton conductivity of around $0.1 \mathrm{~S} \mathrm{~cm}^{-1}$ at $120-180{ }^{\circ} \mathrm{C}$. The implementation of high phosphoric acid content membranes in fuel cells could potentially 
contribute to better performance and longer lifetimes, but introduces challenges with respect to optimization of electrodes and membrane-electrode interfaces.

\section{Supporting Information}

Supporting Information is available from the Wiley Online Library or from the author.

Acknowledgements: This work was financially supported by Innovation Fund Denmark (KDFuelCell, 3047-00007B) and 4M Center (0603-00527B).

Keywords: polybenzimidazole, network, direct casting, polymer electrolyte, fuel cell

\section{References}

[1] Q. Li, R. H. He, J. O. Jensen, N. J. Bjerrum, Chem. Mater. 2003, 15, 4896.

[2] R. Savinell, E. Yeager, D. Tryk, U. Landau, J. Wainright, D. Weng, K. Lux, M. Litt, C. Rogers, J. Electrochem. Soc. 1994, 141, L46.

[3] D. Aili, R. F. Savinell, J. O. Jensen, L. N. Cleemann, N. J. Bjerrum, Q. Li, ChemElectroChem 2014, $1,1471$.

[4] J. S. Wainright, J. T. Wang, D. Weng, R. F. Savinell, M. Litt, J. Electrochem. Soc. 1995, 142, L121.

[5] a) Q. Li, J. O. Jensen, R. F. Savinell, N. J. Bjerrum, Prog. Polym. Sci. 2009, 34, 449; b) J. A. Asensio, E. M. Sanchez, P. Gomez-Romero, Chem. Soc. Rev. 2010, 39, 3210; c) E. Quartarone, P. Mustarelli, Energy Environ. Sci. 2012, 5, 6436.

[6] S. Yuan, X. Guo, D. Aili, C. Pan, Q. Li, J. Fang, J. Membr. Sci. 2014, 454, 351.

[7] J. K. Kallitsis, M. Geormezi, S. G. Neophytides, Polym. Int. 2009, 58, 1226. 
[8] B. Singh, N. M. H. Duong, D. Henkensmeier, J. H. Jang, H. J. Kim, J. Han, S. W. Nam, Electrochim. Acta 2017, 224, 306.

[9] J.-P. Melchior, G. Majer, K.-D. Kreuer, Phys. Chem. Chem. Phys. 2017,19, 601.

[10] A. K. Perry, L. K. More, E. Andrew Payzant, R. A. Meisner, B. G. Sumpter, B. C. Benicewicz, J. Polym. Sci. Part B: Polym. Phys. 2014, 52, 26.

[11] a) J. Yang, D. Aili, Q. Li, Y. Xu, P. Liu, Q. Che, J. O. Jensen, N. J. Bjerrum, R. He, Polym. Chem. 2013, 4, 4768; b) J. Yang, Q. Li, L. N. Cleemann, C. X. Xu, J. O. Jensen, C. Pan, N. J. Bjerrum, R. H. He, J. Mater. Chem. 2012, 22, 11185.

[12] L. X. Xiao, H. F. Zhang, E. Scanlon, L. S. Ramanathan, E. W. Choe, D. Rogers, T. Apple, B. C. Benicewicz, Chem. Mater. 2005, 17, 5328.

[13] R. He, Q. Li, A. Bach, J. O. Jensen, N. J. Bjerrum, J. Membr. Sci. 2006, 277, 38.

[14] X. M. Chen, G. Q. Qian, M. A. Molleo, B. C. Benicewicz, H. J. Ploehn, J. Polym. Sci. Part B: Polym. Phys. 2015, 53, 1527.

[15] a) J. Lobato, P. Cañizares, M. A. Rodrigo, J. J. Linares, J. A. Aguilar, J. Membr. Sci. 2007, 306, 47; b) J. Yang, L. N. Cleemann, T. Steenberg, C. Terkelsen, Q. Li, J. O. Jensen, H. A. Hjuler, N. J. Bjerrum, R. He, Fuel Cells 2014, 14, 7.

[16] J. Park, L. Wang, S. G. Advani, A. K. Prasad, Electrochim. Acta 2014, 120, 30.

[17] S. Singha, T. Jana, ACS Appl. Mater. Interfaces 2014, 6, 21286.

[18] D. Aili, L. N. Cleemann, Q. Li, J. O. Jensen, E. Christensen, N. J. Bjerrum, J. Mater. Chem. 2012, 22, 5444 .

[19] D. Joseph, N. N. Krishnan, D. Henkensmeier, J. H. Jang, S. H. Choi, H.-J. Kim, J. Han, S. W. Nam, J. Mater. Chem. A 2017, 5, 409. 
[20] a) Q. Li, C. Pan, J. O. Jensen, P. Noyé, N. J. Bjerrum, Chem. Mater. 2007, 19, 350; b) D. Aili, Q. Li, E. Christensen, J. O. Jensen, N. J. Bjerrum, Polym. Int. 2011, 60, 1201; c) S. K. Kim, S. W. Choi, W. S. Jeon, J. O. Park, T. Ko, H. Chang, J. C. Lee, Macromolecules 2012, 45, 1438.

[21] S. Yu, B. C. Benicewicz, Macromolecules 2009, 42, 8640.

[22] S. Lai, J. Park, S. Cho, M. Tsai, H. Lim, K. Chen, Int. J. Hydrogen Energy 2016, 41, 9556.

[23] a) H. J. Xu, K. C. Chen, X. X. Guo, J. H. Fang, J. Yin, J. Polym. Sci. Part A: Polym. Chem. 2007, 45, 1150; b) H. J. Xu, K. C. Chen, X. X. Guo, J. H. Fang, J. Yin, J. Membr. Sci. 2007, 288, 255; c) J. Weber, K.-D. Kreuer, J. Maier, A. Thomas, Adv. Mater. 2008, 20, 2595; d) S. Bhadra, N. H. Kim, J. S. Choi, K. Y. Rhee, J. H. Lee, J. Power Sources 2010, 195, 2470; e) S. Bhadra, N. H. Kim, J. H. Lee, J. Membr. Sci. 2010, 349, 304.

[24] A. Sannigrahi, D. Arunbabu, T. Jana, Macromol. Rapid Commun. 2006, 27, 1962.

[25] D. Aili, K. Jankova, J. Han, N. J. Bjerrum, J. O. Jensen, Q. Li, Polymer 2016, 84, 304.

[26] K. Y. Wang, Y. C. Xiao, T. S. Chung, Chem. Eng. Sci. 2006, 61, 5807.

[27] Y. Yuan, F. Johnson, I. Cabasso, J. Appl. Polym. Sci. 2009, 112, 3436.

[28] S. Yu, H. Zhang, L. Xiao, E. W. Choe, B. C. Benicewicz, Fuel Cells 2009, 9, 318.

[29] D. C. Seel, B. C. Benicewicz, J. Membr. Sci. 2012, 405-406, 57.

[30] J.-P. Melchior, K.-D. Kreuer, J. Maier, Phys. Chem. Chem. Phys. 2017, 19, 587.

[31] D. Aili, I. Javakhishvili, J. Han, K. Jankova, C. Pan, S. Hvilsted, J. O. Jensen, N. J. Bjerrum, Q. Li, Macromol. Chem. Phys. 2016, 217, 1161.

[32] K. Kwon, T. Y. Kim, D. Y. Yoo, S. -G. Hong, J. O. Park, J. Power Sources 2009, 188, 463.

[33] a) C. Wannek, I. Konradi, J. Mergel, W. Lehnert, Int. J. Hydrogen Energy, 2009, 38, 9479; b) S. H. Eberhardt, M. Toulec, F. Marone, M. Stampanoni, F. N. Büchi, T. J. Schmidt, J. Electrochem. Soc. 2015, 162, F310; c) H. Becker, L. N. Cleemann, D. Aili, J. O. Jensen, Q. Li, Electrochem. Commun. 2017, 82, 21. 
[34] S. H. Eberhardt, L. Lochner, F. N. Büchi, T. J. Schmidt, J. Electrochem. Soc. 2015, 162, F1367;

b) T. Søndergaard, L. N. Cleemann, H. Becker, D. Aili, T. Steenberg, H. A. Hjuler, L. Seerup, Q. Li, J. O. Jensen, J. Power Sources 2017, 342, 570. 

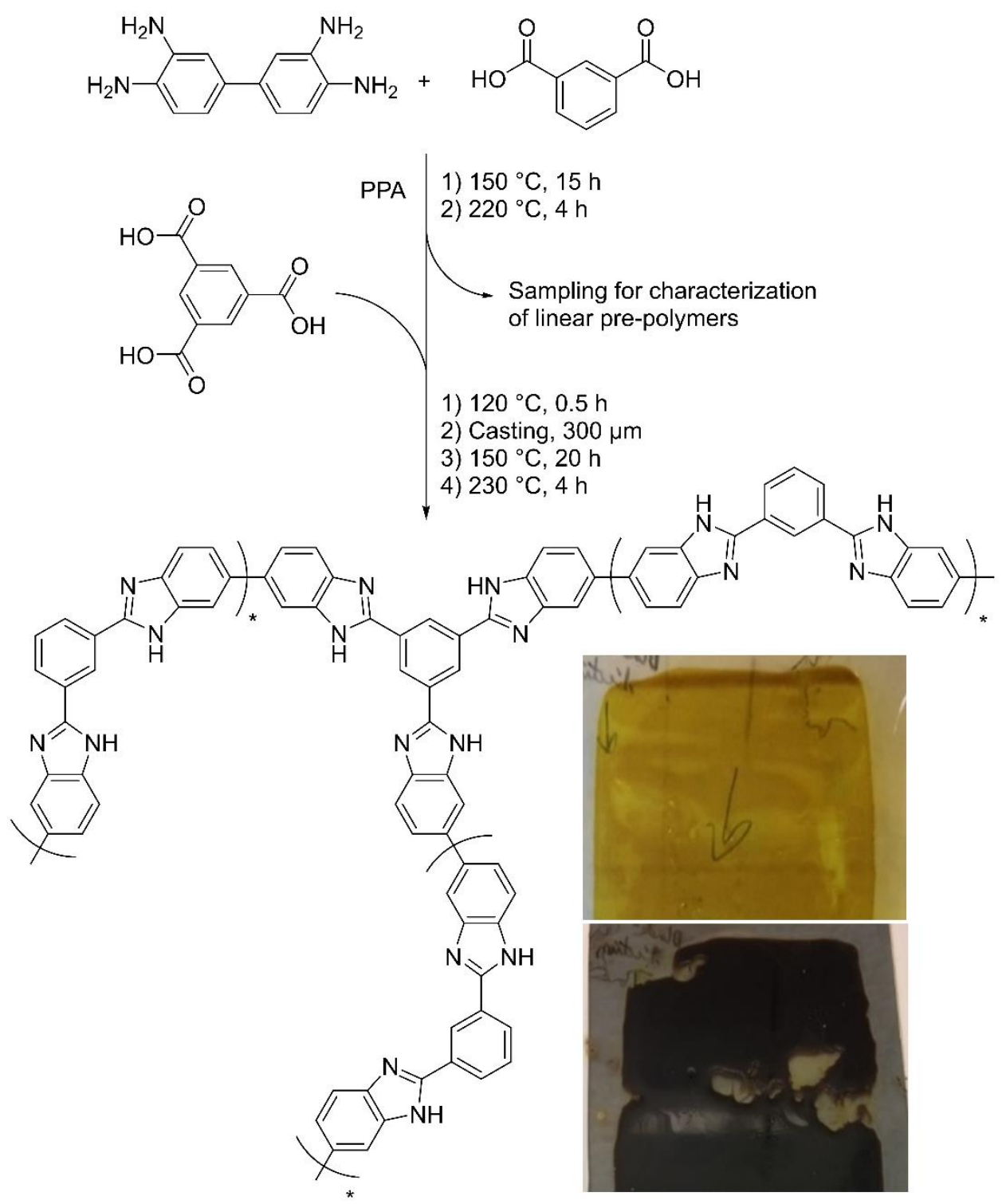

Scheme 1. Reaction scheme of the linear pre-polymer preparation and the subsequent network formation. Photographs of the film obtained for DP50 after casting of the crude solution (top) and after the subsequent heat treatment (bottom). 

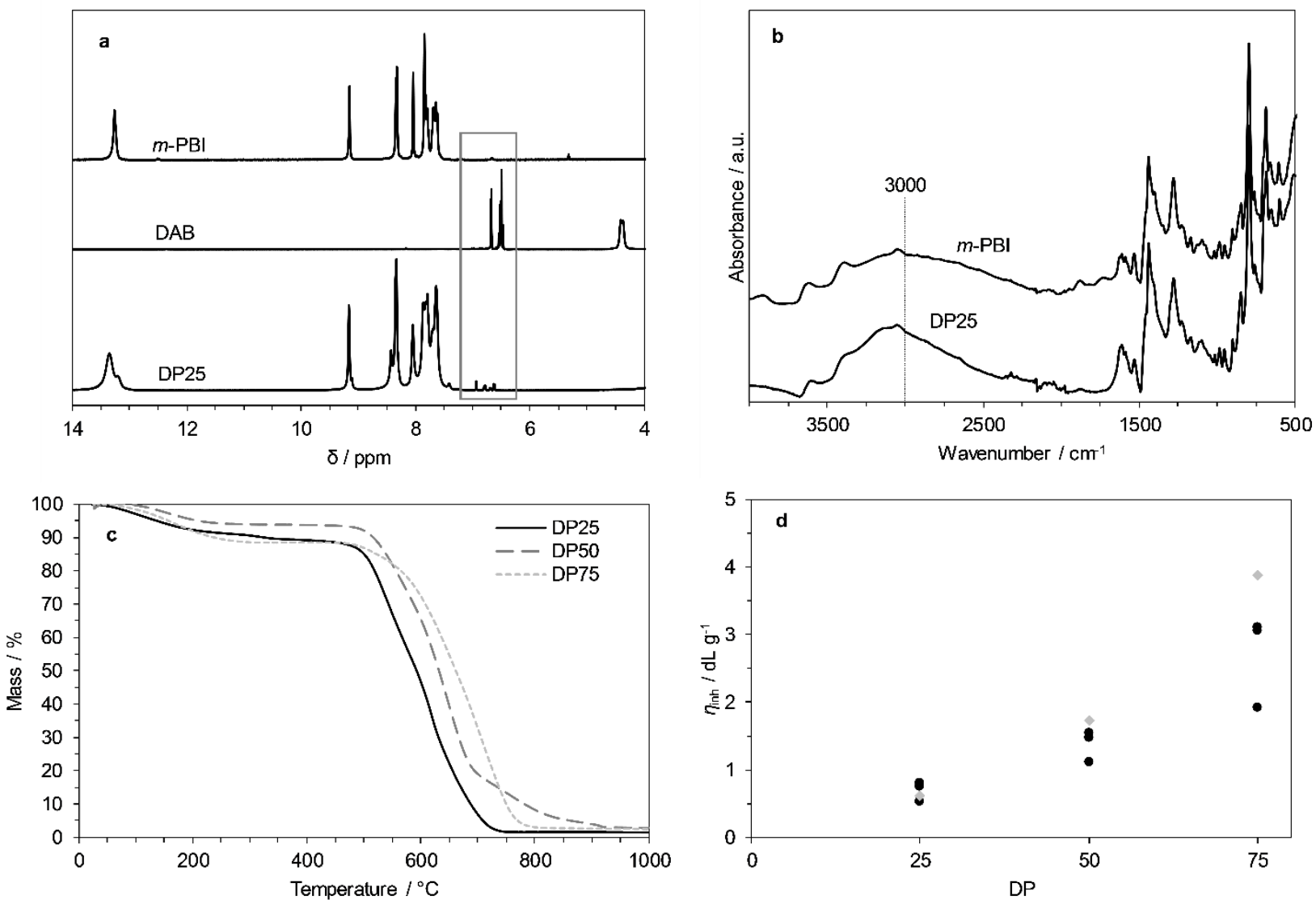

Figure 1. ${ }^{1} \mathrm{H}$ NMR (a), FTIR (b) and TGA (c) of the linear $m$-PBI pre-polymer and the corresponding inherent viscosities (d) as measured in $\mathrm{H}_{2} \mathrm{SO}_{4}$ (black) or DMSO (gray). 

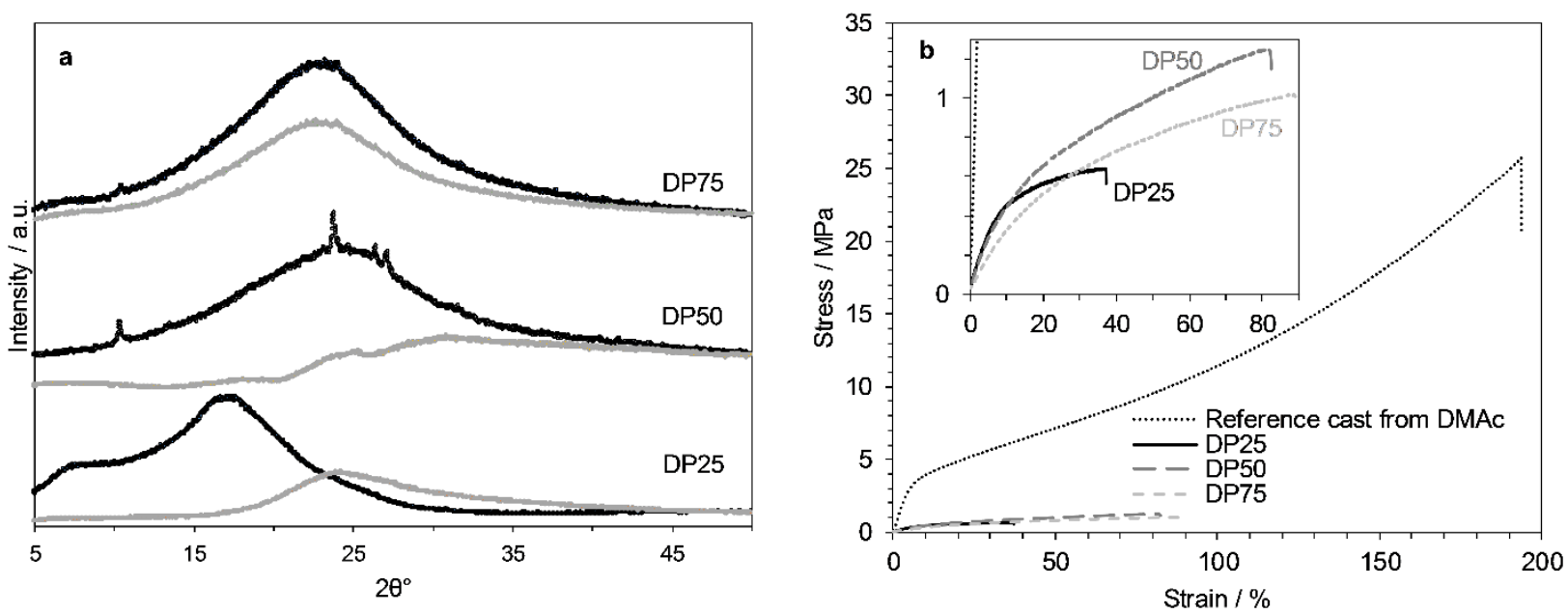

Figure 2. XRD of the membranes after the heat treatment (black) and after the subsequent equilibration in phosphoric acid (gray) (a). Representative stress-strain curves of the phosphoric acid equilibrated network membranes (b).
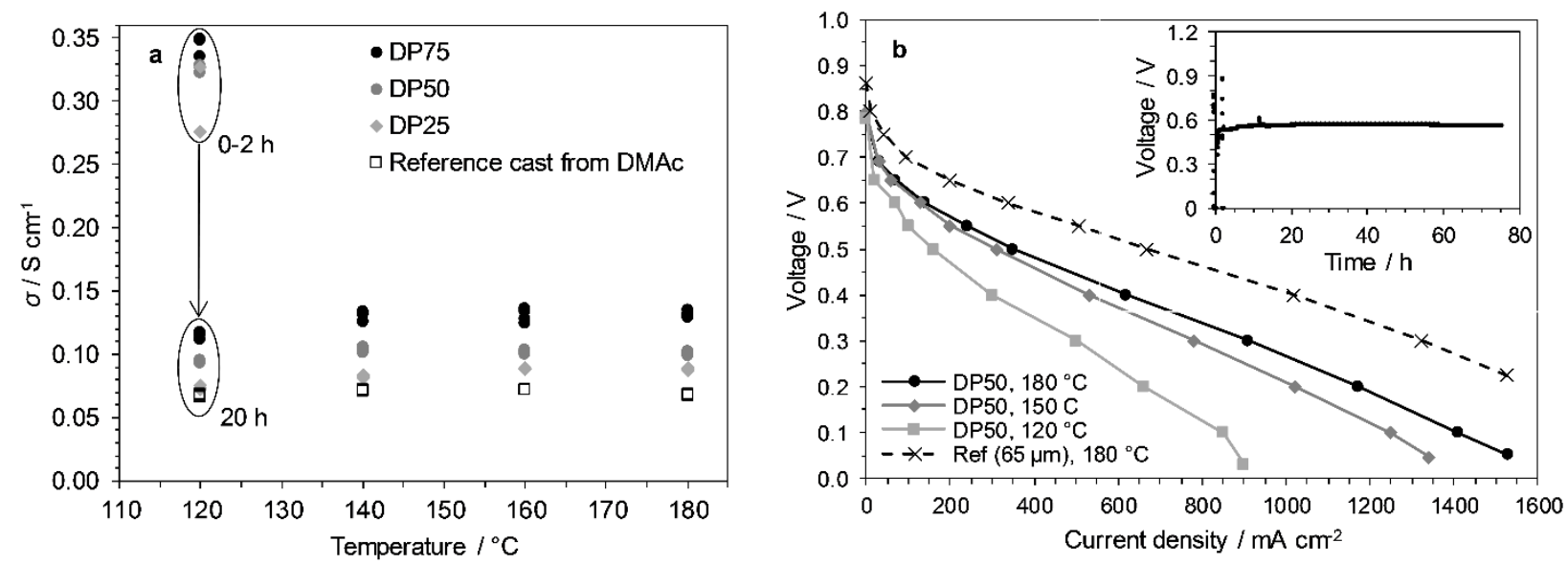

Figure 3. Proton conductivity of the $m$-PBI network membranes at $120-180{ }^{\circ} \mathrm{C}$ after an initial conditioning at $120{ }^{\circ} \mathrm{C}$ for $20 \mathrm{~h}$ (a) and fuel cell polarization curves of a MEA based on the DP50 membrane with a thickness of $300 \mu \mathrm{m}$ (b). Fuel cell data for a cell based on linear $m$-PBI cast from DMAc with a doped thickness of $65 \mu \mathrm{m}$ and $10-11 \mathrm{H}_{3} \mathrm{PO}_{4}$ per polymer repeat unit are shown for comparison. The inset shows the cell voltage evolution at $200 \mathrm{~mA} \mathrm{~cm}^{-2}$ for a cell based on the DP50 membrane operating at $160{ }^{\circ} \mathrm{C}$. 
Table 1. Phosphoric acid contents of the membranes after equilibration in $85 \%$ PA. The corresponding acid doping levels are shown in parenthesis, normalized as $\mathrm{H}_{3} \mathrm{PO}_{4}$ per polymer repeat unit.

\begin{tabular}{lccc}
\hline Membrane & \multicolumn{2}{c}{ Acid content $/ \mathbf{w t} \%\left(\mathbf{A D L}^{\mathrm{a}}\right)$} & Elastic modulus / MPa \\
& Titration & Gravimetry & \\
\hline DP25 & $94.6(55.1)$ & $94.0(49.2)$ & $6.6 \pm 1.6$ \\
DP50 & $92.6(39.3)$ & $94.3(52.0)$ & $5.1 \pm 0.3$ \\
DP75 & $91.3(32.9)$ & $92.0(36.1)$ & $3.1 \pm 0.5$
\end{tabular}

${ }^{\mathrm{a})}$ Calculated based on a repeat unit molecular weight of $308 \mathrm{~g} \mathrm{~mol}^{-1}$. 
Covalent network polybenzimidazole membranes are obtained via a novel sequential direct casting procedure. Free-standing and mechanically robust gel electrolytes are obtained with phosphoric acid contents of up to $95 \mathrm{wt} \%$. It supports high proton conductivity at temperatures well above $100{ }^{\circ} \mathrm{C}$ as ultimately manifested by low internal resistance in fuel cells operating at $180{ }^{\circ} \mathrm{C}$.

A. Kirkebæk, D. Aili,* D. Henkensmeier, J. O. Jensen, Q. Li

Gel electrolytes of covalent network polybenzimidazole and phosphoric acid by direct casting

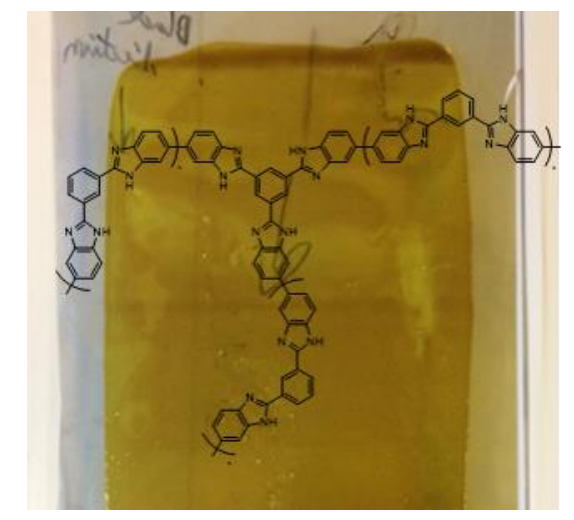




\section{Supporting Information}

for Macromol. Rapid Commun., DOI: 10.1002/marc.2013\#\#\#\#\#

Gel electrolytes of covalent network polybenzimidazole and phosphoric acid by direct casting Andreas Kirkebæk, David Aili, ${ }^{*}$ Dirk Henkensmeier, Jens Oluf Jensen, Qingfeng Li

Table S1. Experimental details for pre-polymer synthesis and membrane formation.

\begin{tabular}{cccccccc}
\hline & \multicolumn{2}{c}{ DAB } & \multicolumn{2}{c}{ IPA } & \multicolumn{2}{c}{ BTA } & \multicolumn{2}{c}{ PPA } \\
& $/ \mathrm{g}$ & $/ \mathrm{mmol}$ & $/ \mathrm{g}$ & $/ \mathrm{mmol}$ & $/ \mathrm{g}$ & $/ \mathrm{mmol}$ & $/ \mathrm{g}$ \\
\hline DP25 & 6.949 & 32.43 & 5.181 & 31.18 & 0.087 & 0.42 & 404 \\
DP50 & 6.949 & 32.43 & 5.282 & 31.80 & 0.045 & 0.21 & 410 \\
DP75 & 6.949 & 32.43 & 5.317 & 32.01 & 0.030 & 0.14 & 408 \\
\hline
\end{tabular}

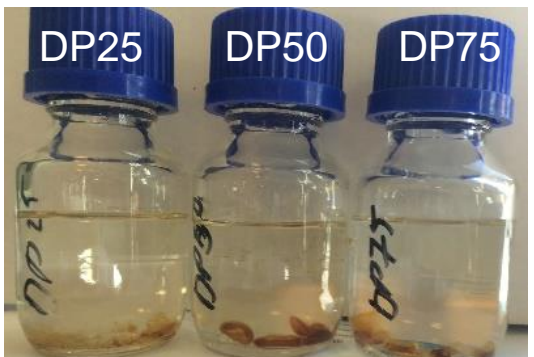

Figure S1. De-doped membranes after treatment in DMAc at $120^{\circ} \mathrm{C}$ for $24 \mathrm{~h}$. 